\title{
漢方治療がもたらす医療経済効果
}

\author{
入院治療を中心として

大野 賢二 ${ }^{\mathrm{a}}$ 関矢 信康 ${ }^{\mathrm{a}}$ 並木 隆雄 ${ }^{\mathrm{a}}$ \\ 笠原 裕司 ${ }^{\mathrm{a}}$ 地野 充時 $\mathrm{a}$ 平崎 能郎 $\mathrm{b}$ \\ 寺澤 捷年b
}

a 千葉大学大学院医学研究院先端和漢診療学講座，千葉， $=260-8670$ 千葉市中央区亥鼻1-8-1

b 千葉大学大学院医学研究院和漢診療学, 千葉， =260-8670 千葉市中央区亥鼻1-8-1

\section{Effects of Kampo Therapy for Inpatient on Medical Economics}

\author{
Kenji OHNO $^{\mathrm{a}}$ Nobuyasu SEKIYA ${ }^{\mathrm{a}}$ Takao NAMIKI $^{\mathrm{a}}$ \\ Yuji KASAHARA $^{\mathrm{a}}$ Atsushi CHINO $^{\mathrm{a}}$ Yoshiro HIRASAKI $^{\mathrm{b}}$ \\ Katsutoshi TERASAWA ${ }^{\mathrm{b}}$
}

a Department of Frontier Japanese Oriental (Kampo) Medicine, Graduate School of Medicine, Chiba University, 1-8-1 Inohana, Chuo-ku, Chiba 260-8670, Japan

b Department of Japanese Oriental (Kampo) Medicine, Graduate School of Medicine, Chiba University, 1-8-1 Inohana, Chuoku, Chiba 260-8670, Japan

\begin{abstract}
We investigated prescriptions and drug costs at admission and discharge for 35 patients hospitalized in Department of Japanese Oriental (Kampo) Medicine, Chiba University Hospital from September 2006 to October 2008. They recovered after Kampo therapy from various non-acute diseases. The number of western drugs decreased from 3.7 at admission to 2.7 at discharge, thus their drug costs per day significantly decreased from 302.1 yen to 227.6 yen. The cost of Kampo medicines themselves, on the other hand, did not decrease significantly. Total drug costs, however, were significantly reduced from 437.8 yen at admission to 348.0 yen at discharge, so patients' overall costs were reduced by $20 \%$. These results indicated that the proper use of Kampo medicine for various diseases would reduce drug costs and the impact of treatment expenses on medical economics, with improvement in disease outcomes.

Key words : medical economics, Kampo medicine, drug costs, medical expenses, inpatient treatment

要旨

千葉大学医学部附属病院和漢診療科の入院患者が入退院時に內服していた薬剤およびその薬剤費を調査した。対 象は2006年 9 月から2008年10月の間に入院した患者のうち, 治療目的以外の入院や急性疾患を除外した35名とした。 疾患内訳は多岐に渡っていたが，転帰が死亡，悪化した症例は認められなかった。西洋薬の薬剤数は入院前後で平 均3.7珮から2.7剂へと減少し, その薬剤費は 1 日当たり302.1円より227.6円へ平均74.5 円推計学的に有意に減少し た。一方, 漢方薬の薬剤費も入院前後で減少した。また, 総薬剤費は入院前後で 1 日当たり平均437.8円から348.0 円へと有意に減少し，約20\%節減できた。以上の結果より，種々の疾患に漢方薬を適正使用することで，患者の病 状が改善すると同時に薬剤費および医療費節減という医療経済的有用性がもたらされる可能性が示された。

キーワード：医療経済，漢方薬，薬剤費，医療費，入院治療
\end{abstract}

\section{緒言}

近年，日本は超高齢社会を迎え，疾病構造が感染 症中心の疾患から慢性疾患やそれに伴う合併症，多 臟器にわたる疾患へと変化してきた。とくに若年者 と比較して慢性疾患の罹患や複数の疾患を有するこ とが多い高齢者は，薬剤の多剤併用や長期投与が行
われる傾向にある。多剤併用は副作用や薬物間相互 作用などの有害作用の発生率の増加にも繋がりやす

く注意が必要な上に，薬剤費の増大を招きやすい ${ }^{1}$ 。 このような状況の中, 平成20年度の日本の総医療 費は34兆円を超えた22)。そのうちの約20\%を占める 薬剂費を節減するために，後発品使用促進等の対策 
表 1 対象の疾患別内訳

\begin{tabular}{lc}
\hline 疾患分類 & 症例数 \\
\hline 慢性疼痛 & 7 \\
消化器 & 6 \\
神経 & 5 \\
整形外科 & 4 \\
悪性腫痬 & 2 \\
䍘科·口腔外科 & 2 \\
循環器 & 1 \\
耳兽·咽喉 & 1 \\
精神 & 1 \\
代謝·内分泌 & 1 \\
皮虚 & 1 \\
その他 & 4 \\
\hline
\end{tabular}

が取られている。また，急性期入院医療費に関して は，2003年度より出来高払い制度から DPC（diagnosis procedure combination）を用いた包括支払い制 度へと一部移行し，医療の標準化，効率化，質の向 上と共に医療費の抑制が図られている。

現在, 漢方薬は保険診療の枠組みの中で多くの医 師により使用され，西洋薬と併用される機会も多 ( ${ }^{3 / 4)}$ 。既に，個々の疾患や療養型病床群における漢 方治療の医療経済的有用性は多数報告されているが, 複数の疾患を対象とした横断的調査は未だ行われて いない。そこで今回, 千葉大学医学部附属病院和漢 診療科の入院治療において, 漢方薬が及ぼす医療経 済効果について調査・検討を行ったので報告する。

\section{方法}

本調査の対象は2006年 9 月から2008年10月の間に 千葉大学医学部附属病院和漢診療科に入院した患者 全46名のうち，漢方治療の効果を評価し得ない転科， 精査，教育，母子分離目的の入院掞よび急性疾患を 除外した35名とした。調査項目は入院時と退院時に 内服していた薬剤掞よびその薬剤費とし，頓服薬や 外用薬, 注射薬は正確な薬品名や使用量の把握が困 難なため除外した。統計解析には Wilcoxon signedrank test を用い, $p<0.05$ 有意差ありとした。

\section{結果}

対象患者の疾患別内訳を表 1 に示す。疼痛性疾患 が最も多く, 次いで消化器, 神経疾患が多かった。 患者背景は男性13名，女性22名，平均年齢60.6土 18.1歳, 平均在院日数 $28.5 \pm 13.0$ 日であった。転
表 2 廃薬・追加となった西洋薬剤一覧

\begin{tabular}{|c|c|c|}
\hline 薬品分類 & 廃薬症例数 & 追加症例数 \\
\hline 消化性潰湯治療薬 & 10 & 3 \\
\hline 解熱·鎮痛·抗炎症薬 & 5 & 0 \\
\hline 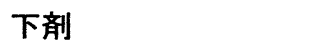 & 4 & 0 \\
\hline 抗うつ薬 & 4 & 0 \\
\hline 抗不安薬 & 4 & 1 \\
\hline 健胃·消化薬 & 2 & 0 \\
\hline 抗不整脈薬 & 2 & 0 \\
\hline 高脂血症用薬 & 2 & 2 \\
\hline 止痢·整腸薬 & 2 & 1 \\
\hline ビタミン製剂 & 1 & 0 \\
\hline 過敏性腸症候群治療薬 & 1 & 0 \\
\hline 去痰薬 & 1 & 0 \\
\hline 経腸栄養製剂 & 1 & 0 \\
\hline 抗けいれん薬 & 1 & 0 \\
\hline 抗精神病薬 & 1 & 0 \\
\hline 降圧薬 & 1 & 1 \\
\hline 催眠鎮静薬 & 1 & 0 \\
\hline 鉄剂 & 1 & 0 \\
\hline 泌尿·生殖器用薬 & 1 & 0 \\
\hline 利尿薬 & 1 & 0 \\
\hline 糖尿病薬 & 0 & 1 \\
\hline
\end{tabular}

帰は全治 1 例，略治 1 例，軽快 33 例であった。

西洋薬の平均薬剂数は入院時 $3.7 \pm 3.2$ 剂から退 院時 $2.7 \pm 2.6$ 凪へと減少した。入院中に廃薬・追 加となった西洋薬剤一覧を表 2 に示す。廃薬となっ た薬剤は消化性潰瘍治療薬が最も多く, 次いで解熱 ·鎮痛・抗炎症薬, 下凨, 抗うつ薬, 抗不安薬が多 かった。

1 日当たりの平均薬剤費を図 1 に示す。西洋薬の 薬剂費は入院時 302.1 円から退院時 227.6 円へと 74.5 円有意に減少し, 漢方薬の薬剂費は入院時 135.7 円 から退院時120.4円へと有意差はないものの15.3円 減少した。また, 西洋薬と漢方薬の合計の総薬剤費 は，入院時 437.8 円から退院時 348.0 円へと 89.8 円有 意に減少した。具体的症例を提示する。患者は77歳 女性で 5 年前より出現した舌の痛みと乾燥感を主訴 に入院。甘草瀉心湯と桂枝获苓丸の投与により症状 の改善を認め，鎮痛剤が不要となった。併せて内服 薬の整理を行ったところ表 3 に示すように総薬剤費 が1033.5円から527.5円へと減少した。

主に服用していた漢方薬の凨型に関しては, 入院 前後でエキス製剤から煎じ薬に変更になった患者が 


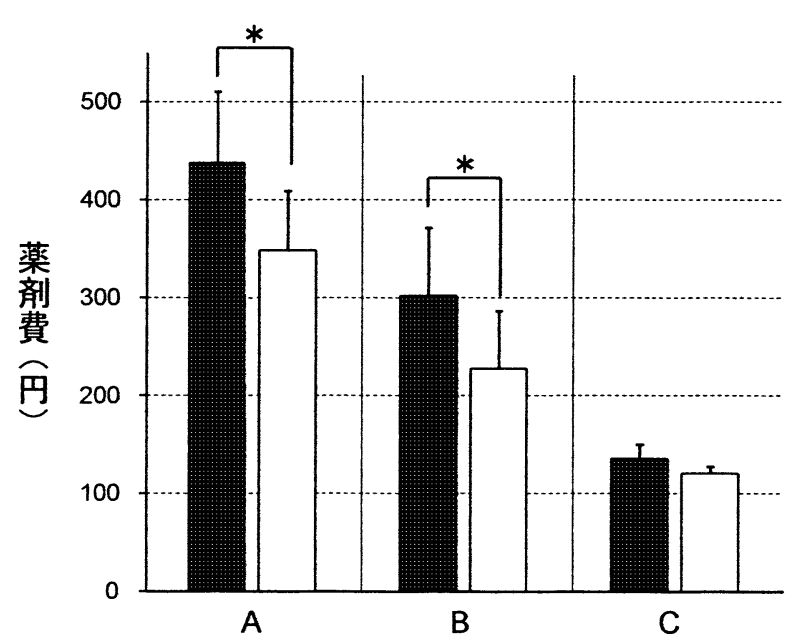

図 11 日当たりの平均薬剂費

$\square$ : 入院時の薬剤費 $\square$ : 退院時の薬剤費 $\mathrm{A}$ : 総薬剂費 $\mathrm{B}$ : 西洋薬の薬剂費 $\mathrm{C}$ : 漢方薬の薬剤費 * $\quad P<0.05$

17 名と最も多く, 入院前後共に煎じ薬であったのは 16名，エキス製剤であったのは 1 名であった。また， 入院時に漢方薬を何も服用しておらず，退院時に煎 じ薬が処方されていた患者は 1 名であった。

\section{考察}

日本の莫大な総医療費を節減する 1 つの手段とし て，医療費の約 $20 \%$ を占める薬剤費の抑制が挙げら れ, 具体的には不必要な薬剤の廃薬, 安価な薬剤へ の変更，薬剂費の低い治療法への変更等が考えられ る。薬剤減量につながる漢方治療の指針 5 ) 等を参考 に日常診療に漢方薬を導入することで，併用薬剤を 廃薬，減量できる例は少なくない。

本調査でも, 入院前後で西洋薬剤数が平均 1 剂減 少し，多剂併用が抑制された。また，1日当たりの 総薬剤費は入院時平均 437.8 円から, 平均 89.8 円減 少し, 約 $20 \% の$ 薬剂費が節減できた。つまり，1年 間（365日）では平均32,777円の節減が見込める計 算となるが, 国民 1 人当たりの年間医療費が 267,000 円である2)ことを考慮すると，この金額は決して小 さくない。

しかし，当院はDPC 対象病院であるため薬剤費 の節減は病院の収益には繋がるものの, 医療費の直 接的節減には影響を及ぼさない。ただし，もし本調 査結果を外来診療や出来高報酬制度等に導入すれば, 漢方治療により薬剤費が約20\%節減できる可能性が あり，その効果は大きいと推測される。

一般的に, 漢方薬はエキス製凨より煎じ薬の方が
表 3 薬剤費節減の具体例

\begin{tabular}{|c|c|c|c|c|c|}
\hline \multicolumn{3}{|c|}{ 入院時 } & \multicolumn{3}{|c|}{ 退院時 } \\
\hline 菜都名 & 用量 & 薬刘费 (円) & 薬夙名 & 用量 & 菜用费 (开) \\
\hline アムロジンOD(5)・ & 鏔 & 75.6 & アムロジンOD (2.5)・ & 2鏔 & 81.0 \\
\hline パナルジン $(100)^{\bullet}$ & 1 鏔 & 67.1 & パナルジン $(100)^{\ominus}$ & 1 錇 & 67.1 \\
\hline ベシケア (5)・ & 1 鏔 & 192.7 & ミカルディス $(40)^{\bullet}$ & 0.5 绽 & 77.1 \\
\hline ロプ(60) & 3鏥 & 20.7 & ベイスンOD $(0.2)^{\bullet}$ & 3鍰 & 142.5 \\
\hline パリエット(20)・ & 镜 & 338.4 & ツムラ麻子仁丸エキズ & 2包 & 38.5 \\
\hline ガスロンN(2)・ & 2鏔 & 76.0 & 桂枝获苓丸（丸菜） & 3丸 & 11.0 \\
\hline ドクマチール $(50)^{\bullet}$ & 3唋 & 55.2 & 甘草核心湯 (想し莱) & & 110.3 \\
\hline ビオフェルミン鋌・ & 3銥 & 18.6 & & & \\
\hline レンドルミン $(0.25)^{\bullet}$ & 谖 & 31.7 & & & \\
\hline ツムラ滋陵至宝晹エキス゚ & 3包 & 157.5 & & & \\
\hline 合㝇 & & 1033.5 & 合計 & & 527.5 \\
\hline
\end{tabular}

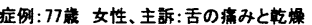

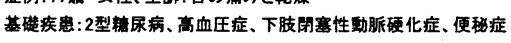

薬剂費が安くなる傾向にある。今回, 漢方薬の薬剤 費が減少したのは，入院前後で主方がエキス製剤か ら煎じ薬に変更となった患者が17名いたためと考え られる。また，統計的に有意差が出なかったのは， 煎じ薬を構成する生薬の中でも比較的薬価が高い烏 頭や人参の使用量が多かったことが可能性として挙 げられる。本調査では，漢方薬の製剤変更によって も薬剤費の節減が可能となったが, 漢方薬は西洋薬 に比べて薬価が低いため, 西洋薬から漢方薬への変 更も薬剂費の節減に有効と考えられる ${ }^{6)}$ 。

赤瀬らは，かぜ症候群や鉄欠乏性貧血の治療には， 西洋薬単独よりも漢方薬単独治療の方が, 有効性, 安全性が高いことに加え, 経済的にも薬剂費が約 30 -40\%削減できることを報告している78)。また，井 齋らは急性膀胱炎の治療には, 抗菌剤の単独治療よ りも漢方薬を基本に抗菌剤を短期間併用する方がよ り効果的で経済的にも薬剂費を削減できることを報 告している99。

さらに, 肝硬変や再燃率の高い急性細菌性呼吸器 感染症, 認知症扮よびその周辺症状, MRSA 感染 症, 脳梗塞後の不定愁訴の治療や療養型病床群にお ける治療に漢方薬を導入することで, 薬剤費や医療

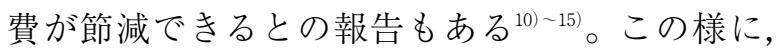
個々の疾患の治療に漢方薬を導入することで, 薬剤 費や医療費を節減できたという報告は散見される。

一方, 本調査の対象患者の疾患別内訳は表 1 に示 すように多岐に渡っていたが，その転帰は全治，略 治，軽快のいずれかであった。このように，複数の 疾患を対象としても，漢方薬を適正使用すれば，患 
者の病状が改善すると同時に薬剤費の節減が可能で あることが示された。疾患が多岐に渡る理由は漢方 治療の特徵が西洋医学的な病名治療ではなく, 全人 的医療にあることが理由と考えられる。

入院治療における医療費節減には, 在院日数の短 縮も重要な要素である。漢方薬は術後の全身状態の 管理に非常に有用であり, 在院日数の短縮に寄与し

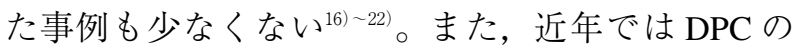
導入により在院日数が短縮され, 平成 20 年の一般病 床に扔ける平均在院日数は 18.8 日となっている ${ }^{23)}$ 。 本調査の平均在院日数は28.5日と長期であったが, この理由として, 当科では西洋医学的に難治の症例 を対象とすることが多く, 疼痛緩和に時間を要した り，患者の退院意欲が低いこと等が挙げられる ${ }^{2425)}$ 。 また, 廃薬となった西洋薬剤は消化性潰瘍治療薬や 解熱 - 鎮痛 - 抗炎症薬, 下凨, 抗うつ薬, 抗不安薬 が多く認められたが，これらは原因不明の慢性疼痛 や器質的に異常の認められない消化器疾患等の治療 に処方されやすい薬剤と考えられる。

漢方薬の有効性や安全性については, 既に多くの 無作為化比較試験が実施され, Evidence が蓄積され つつあり, 各疾患の診療ガイドラインにも漢方薬が 導入されつつある。本調査は種々の疾患に漢方薬を 適正使用することで, 患者の病状が改善すると同時 に薬剂費や医療費節減という医療経済的有用性をも たらすことを明らかにした後ろ向き研究であるが, 同様の報告は少ない。今後は, 薬剂費の他にも検査 料や調剂, 介護, 人件費等の周辺諸費用も考慮した 総合的, 客観的評価を積極的に行い, 漢方薬の医療 経済的有用性を示していく必要があると考えられる。

漢方医学は日本独自の伝統医学であり, 西洋薬と 漢方薬の両方を同時に処方できるのは日本でのみ実 施されている医療制度である。また, 漢方薬は保険 診療の枠組みの中で30年以上に渡り幅広く使用され 続けており，患者により経済的かつ効率的な最善の 医療を提供する上で久かすことのできない治療手段 の1つとなっていることは論を待たない。

\section{文献}

1) 鳥羽研二, 秋下雅弘, 水野有三, 江頭正人, 金 承範, 阿古潤哉, 寺本信嗣, 長瀬隆英, 長野宏一朗, 須藤紀 子, 吉栖正雄, 難波吉雄, 松瀬 健, 大内尉義: 薬剤 起因性疾患. 日本老年医学会雑誌, 36, 181-185, 1999
2 ) 厚生労働省 厚生労働省保険局調查課：平成20年度 医療費の動向

3 ）漢方薬使用実態調査2007：Nikkei Medical10月号別冊 付録，日経メディカル開発，東京，2007

4 ) 五十嵐信智, 志村彩香, 竹澤 崇, 武藤麻美, 戸田雄 大, 伊藤清美, 木村孝良, 秋葉哲生, 入江祥史, 渡辺 賀子, 福澤素子, 石井弘一, 渡辺賢治, 杉山 清: 漢 方専門外来受診患者における漢方薬服用に関する実態 調査 I - 漢方薬と西洋薬の併用一. 医療薬学, 33, 353-358，2007

5 ) 喜多敏明，寺澤捷年：漢方処方は薬剤減量につながる か. JIM, 8，392-394，1998

6 ) 赤瀬朋秀: 漢方薬は患者・病院どちらにも経済的一医 療経済から見た漢方薬．科学，75，839-841，2005

7 ) 赤瀬朋秀, 秋葉哲生, 井齋偉矢, 鈴木重紀 : かぜ症候 群における薬剤費の薬剤疫学および経済学的検討一漢 方薬と西洋薬の経済性における比較研究一. 日本東洋 医学雑誌, 50, 655-663, 2000

8 ）赤瀬朋秀, 望月眞弓, 佐川賢一, 島田慈彦, 田代眞一, 鶴田陽和, 西島正博 : 疫学的手法も用いた漢方薬の薬 効および経済性の評価一鉄欠乏性貧血に対する当帰药 薬散の効果一. 産婦人科漢方研究のあゆみ, 13, 6265, 1996

9 ) 井齋偉矢 : 東洋医学を基準とするパラダイムへの変換, 補完, 代替医療の視点から西洋医学を見直す. 岩見沢 市立総合病院医誌，27，1-3，2001

10）小川京子, 岡 博子, 藤野志朗: 肝硬変に抄ける小柴 胡湯のコスト・エフェクティブネス分析. 薬理と治療, 23, 2181-2189, 1995

11）三鴨廣繁, 玉舎輝彦: 医療経済的見地からみた感染症 治療における漢方治療の有用性. 産婦人科漢方研究の あゆみ，24，105-108，2007

12）赤瀬朋秀：高齢者医療における漢方製剂の有用性一医 療経済の視点から一。医薬ジャーナル，43，97-102, 2007

13）坂巻弘之：医療経済と漢方. 日経メディカル， 5, 10, 2001

14）下手公一, 今岡かおる, 河野直人, 松井龍吉, 豊田元 哉, 小黒浩明, 小林祥美, 寺澤捷年: 療養型病床群に 於ける漢方治療導入の医療経済効果. 医療経営情報, 113，16-18， 1999

15）針生雄吉：杜都中央病院の高齢者医療における漢方薬 治療の経済的効果及び臨床効果について. 漢方の臨床, 50, 1547-1550, 2003

16）今津嘉宏, 渡辺賢治, 今井栄子, 上田政和, 北島政樹： 大腸癌手術における大建中湯の入院日数短縮効果につ いて. Progress in Medicine, 24, 1398-1400, 2004

17）壁島康郎, 高橋洋子, 龟山哲章, 戸泉 篤, 田村洋一 郎, 影山隆久：大腸癌手術症例における大建中湯を用 いた術後リハビリテーションの検討. 日本消化器外科 学会雑誌, 38, 592-597, 2005

18）水野修吾, 山際健太郎, 岩田真, 田端正己, 田岡大樹, 伊佐地秀司, 横井一, 野口孝, 川原田嘉文: 胃癌切 除後の消化器症状に対するツムラ六君子湯の術後早期 
投与一逆流性食道炎を中心として一. Progress in Medicine, 21，1366-1367，2001

19）山村晋史, 園田耕三, 大城辰雄, 太田正之, 石川哲大, 西崎 隆, 田代英哉, 松坂俊光, 久米一弘: 腹部大動 脈瘤術後の腸管蠕動回復に対する大建中湯と大黄甘草 湯の有用性. Progress in Medicine, 22, 1350-1351, 2002

20）笠原裕司, 関矢信康, 地野充時, 並木隆雄, 大野賢二, 来村昌紀, 橋本すみれ, 小川恵子, 平崎能郎, 寺澤捷 年: 腎癌術後の腹部症状に漢方治療が奏効した一例. 日本東洋医学雑誌，60，385-389，2009

21）地野充時, 関矢信康, 大野賢二, 橋本すみれ, 小川恵 子, 来村昌紀, 平崎能郎, 笠原裕司, 喜多敏明, 並木 隆雄，寺澤捷年：開腹術後愁訴に対し香蘇散料が有効 であった 2 症例. 日本東洋医学雑誌, 60, 459-463, 2009

22）小川恵子，並木隆雄，関矢信康，笠原裕司，地野充時,
来村昌紀, 橋本すみれ, 大野賢二, 寺澤捷年 : 㷌者建 中湯加烏頭が有効であった術後腰部脊柱管狭乍症の 1 例. 日本東洋医学雑誌，60，167-170，2009

23）厚生労働省 大臣官房統計情報部人口動態 - 保健統計 課保健統計室: 平成20医療施設 (静態 - 動態) 調査 · 病院報告の概況

24）西洋医学的治療では難治性であった便通異常に延年半 夏湯が奏効した 1 例：王子剛，笠原裕司，小川恵子, 大野賢二, 橋本すみれ, 来村昌紀, 平崎能郎, 林克美, 地野充時, 関矢信康, 並木隆雄, 寺澤捷年. 漢方の臨 床，55，737-739，2008

25）橋本すみれ，地野充時，来村昌紀，王子剛，小川恵子, 大野賢二, 平崎能郎，林 克美，笠原裕司，関矢信康， 並木隆雄, 寺澤捷年 : 線維筋痛症に対し白虎湯加味方 が著効した症例. 日本東洋医学雑誌，60，171-175, 2009 